\title{
ON WEIGHTED GENERALIZATION OF THE HERMITE-HADAMARD INEQUALITY
}

\author{
ROZARIJA JAKŠIĆ, LJILJANKA KVESIĆ AND JOSIP PEČARIĆ
}

\begin{abstract}
The results obtained in this paper are a correction of the main results obtained in [14], for which we also give an alternative proof and improvement. We also study some new monotonic conditions under which various generalizations of the Hermite-Hadamard inequality are valid. Furthermore, we give an improvement of the obtained results.
\end{abstract}

Mathematics subject classification (2010): 26A48, 26A51, 26D99.

Keywords and phrases: Hermite-Hadamard's inequality, generalized Hermite-Hadamard's inequality, convex functions, positive linear functionals.

\section{REFERENCES}

[1] P. R. BEESACK, J. E. PeČARIĆ, Integral inequalities for concave functions with applications to special functions, Proc. Roy. Soc. Edinburgh Sect. A 118 (1991), No. 1-2, 173-192.

[2] J. L. BRenner, H. Alzer, On the Jessen's inequality for convex functions, J. Math. Anal. Appl. 110 (1985), 536-552.

[3] S. S. Dragomir, J. E. PeČarić, L. E. Persson, Some inequalities of Hadamard type, Sochow J. of Math. (Taiwan), 21, (1995), No. 3, 335-341.

[4] S. S. Dragomir, J. E. PeČArić, A generalization of Hadamard's inequality for isotonic linear functionals, Rad. Mat., 7 (1991), No. 1, 103-107.

[5] L. FeJÉR, Über die Fourierreihen, II, Math. Natur wiss. Anz Ungar. Akad Wiss., 24 (1906), 369-390.

[6] P. M. GILl, C. E. M. PeARCE, J. PeČARIĆ, Hadamard's inequality for $r$-convex functions, J. Math. Anal. Appl., 215 (1997), 461-470.

[7] B. JESSEN, Bemaerkinger om konvekse Funktioner og Uligheder imellem Middelvaerdier I, Mat. Tidsskrift, B (1931), 17-28.

[8] M. KlariČIĆ BAKUla, J. PeČArIĆ, J. Perić, Extensions of the Hermite-Hadamard inequality with applications, Math. Inequal. Appl., 15, 4 (2012), 899-921.

[9] M. Klaričić Bakula, J. E. PeČArić, J. Perić, On the converse Jensen inequality, Applied Mathematics and Computation 218 (2012) 6566-6575.

[10] D. S. Mitrinović, I. B. Lacković, Hermite and convexity, Aequationes Math., 28, 229-232.

[11] D. S. Mitrinović, J. E. PeČArić, A. M. FinK, Classical and new inequalities in Analysis, Mathematics and its Applications (East European Series), 61, Kluwer Academic Publishers Group, Dordrecht, 1993, ISBN 0-7923-2064-6.

[12] J. E. PeČarić, F. Proschan, Y. L. Tong, Convex functions, Partial orderings and statistical applications, Academic Press Inc., San Diego 1992.

[13] J. F. StEFFEnSEn, En Ulighed mellem Middelve edier, Mat. Tidsskrift, B (1920), 49-53.

[14] G. Zabandan And A. KiliçMan, Several integral inequalities and upper bound for the bidimensional Hermite - Hadamard inequality, Journal of Inequalities and Applications 2013, 2013:27. 